Correction

\title{
Correction: Hill, A.; et al. Effects of Vitamin C on Organ Function in Cardiac Surgery Patients: A Systematic Review and Meta-Analysis. Nutrients $2019,11,2103$
}

\author{
Aileen Hill 1,2,3,*®D, Kai C. Clasen 1,2,3, Sebastian Wendt 2,3 , Ádám G. Majoros 1,4, \\ Christian Stoppe ${ }^{1,3}$, Neill KJ Adhikari ${ }^{5}\left(\mathbb{0}\right.$, Daren K. Heyland ${ }^{6}\left(\mathbb{C}\right.$ ) and Carina Benstoem ${ }^{1,3, *}$ \\ 1 Department of Intensive Care Medicine, Medical Faculty RWTH Aachen, D-52074 Aachen, Germany; \\ kaclasen@ukaachen.de (K.C.C.); adam.majoros@rwth-aachen.de (Á.G.M.); \\ christian.stoppe@googlemail.com (C.S.) \\ 2 Department of Anesthesiology, Medical Faculty RWTH Aachen, D-52074 Aachen, Germany; \\ wendt_s@gmx.net \\ 3 3CARE-Cardiovascular Critical Care and Anesthesia Evaluation and Research, D-52074 Aachen, Germany \\ 4 Medical Faculty, RWTH Aachen University, D-52074 Aachen, Germany \\ 5 Department of Critical Care Medicine, Sunnybrook Health Sciences Centre; Interdepartmental Division of \\ Critical Care Medicine, University of Toronto, Toronto, ON M4N 3M5, Canada; neill.adhikari@utoronto.ca \\ 6 Clinical Evaluation Research Unit, Kingston General Hospital, Kingston, CA K7L 2V7, Canada; \\ dkh2@queensu.ca \\ * Correspondence: ahill@ukaachen.de (A.H.); cbenstoem@ukaachen.de (C.B.); Tel.: +49-241-8038166 (A.H.); \\ $+49-241-8038038$ (C.B.)
}

The authors thank the readers for pointing out the issues [1] in their publication [2], and wish to make a correction in the published version of their paper as the response of the readers' Comment. $p$-values have been corrected in the following parts of the paper.

In Abstract: Vitamin $C$ significantly decreased the incidence of atrial fibrillation $(p<0.0001)$, ventilation time $(p=0.0003)$, intensive care unit (ICU) length-of-stay $(p=0.002)$, and hospital length of stay $(p=0.03)$. However, on average, vitamin $C$ had no significant effects on in hospital mortality $(p=0.59)$, or on the incidence of stroke $(p=0.32)$.

In Section 4.2. Cardiac Function

On average, a significant effect in favor of vitamin $C$ was observed $(p<0.0001$, CI 0.46 to 0.77$)$.

In Section 4.3. Pulmonary Function

On average, the effect of vitamin $C$ was significant on reduction of ventilation time $(p=0.0003$, $\mathrm{CI}-3.99$ to -1.18$)$; we observed no statistical heterogeneity $\left(\mathrm{I}^{2}=0 \%\right)$.

In Section 4.6. In-Hospital Mortality

On average, no significant effect of vitamin $C$ was found on in-hospital mortality $(p=0.59$, CI 0.21 to 2.40$)$. 
In Section 4.7. Length of Stay

On average, a significant effect favoring vitamin $\mathrm{C}$ administration regarding ICU length-of stay (LOS) was detected ( $p=0.002, \mathrm{CI}-9.66$ to -2.14$)$.

On average, there was a significant effect in favor of vitamin C regarding hospital LOS ( $p=0.03$, CI -34.49 to -1.41$)$.

In Section 4.8. Subgroup Analysis Influence of Administration Route: Intravenous Administration versus Oral Administration of Vitamin C.

A total of eight studies contributed reported the outcome "cerebral ischemic events" and contributed to the subgroup analysis investigating any possible influence of the route of administration. In four of the eight studies, cerebral ischemic events occurred and the evidence suggested no difference in treatment effect (test for subgroup differences $\left(\mathrm{Chi}^{2}=0.09, d f=1(p=0.99), \mathrm{I}^{2}=0 \%\right)$.

A total of eight studies contributed to the subgroup analysis investigating any possible influence of the route of administration on the outcome incidence of "atrial fibrillation". While the effect of the treatment was statistically significant in the group receiving intravenous vitamin C ( $p=0.002, \mathrm{CI} 0.53$ to $\left.0.87, \mathrm{I}^{2}=0 \%\right)$, it was not in patients receiving oral vitamin $\mathrm{C}\left(p=0.09, \mathrm{CI} 0.19\right.$ to $\left.1.13, \mathrm{I}^{2}=74 \%\right)$. However, the test for subgroup differences $\left(\mathrm{Chi}^{2}=0.69, d f=1(P=0.41), \mathrm{I}^{2}=0 \%\right)$ shows no evidence that the effect of vitamin $C$ is different between the trials that used intravenous administration and those that used oral administration on the outcome incidence of "atrial fibrillation".

A total of four studies contributed to the subgroup analysis investigating any possible influence of the route of administration on the outcome "duration of mechanical ventilation". We found a statistical significance in the group receiving intravenous vitamin C $\left(p=0.05, \mathrm{CI}-15.52\right.$ to $-0.08, \mathrm{I}^{2}$ not applicable); however, this group included only one RCT with 58 patients in total. In the group of oral vitamin $C$ administration, the treatment effect did not reach statistical significance $(p=0.10$, CI -6.22 to $\left.0.54, \mathrm{I}^{2}=0 \%\right)$. The test for subgroup differences $\left(\mathrm{Chi}^{2}=1.89, d f=2(p=0.39), \mathrm{I}^{2}=0 \%\right)$ shows no evidence that the effect of vitamin $C$ is different between the trials that used intravenous administration and those that used oral administration on the outcome incidence of "duration of mechanical ventilation".

A total of eight studies contributed to the subgroup analysis investigating any possible influence of the route of administration on the outcome "in-hospital mortality". We found no evidence of a treatment effect between subgroups (test for subgroup differences $\left(\mathrm{Chi}^{2}=0.26, d f=1(p=0.61)\right.$, $\left.\mathrm{I}^{2}=0 \%\right)$.

A total of nine studies contributed to the subgroup analysis investigating any possible influence of the route of administration on the outcome "ICU-LOS". We found no statistically significant effects in the group receiving intravenous vitamin $C\left(p=0.12, \mathrm{CI}-9.64\right.$ to $\left.1.07, \mathrm{I}^{2}=68 \%\right)$, but in the group of oral vitamin $C$ administration, the treatment effect did reach statistical significance $(p=0.0003$, $\mathrm{CI}-11.98$ to $\left.-3.53, \mathrm{I}^{2}=0 \%\right)$. The test for subgroup differences $\left(\mathrm{Chi}^{2}=1.00, d f=1(p=0.32), \mathrm{I}^{2}=0 \%\right)$ shows no evidence that the effect of vitamin $C$ is different between the trials that used intravenous administration and those that used oral administration on the outcome "ICU-LOS".

A total of eight studies contributed to the subgroup analysis investigating any possible influence of the route of administration on the outcome "hospital-LOS". We found no statistical significance in the group receiving intravenous vitamin $C\left(p=0.36, C I-45.51\right.$ to $\left.16.71, \mathrm{I}^{2}=91 \%\right)$, but in the group of oral vitamin $C$ administration, the treatment effect did reach statistical significance $(p=0.01, \mathrm{CI}-20.07$ to $\left.-2.36, \mathrm{I}^{2}=81 \%\right)$. The test for subgroup differences $\left(\mathrm{Chi}^{2}=0.04, d f=1(p=0.85), \mathrm{I}^{2}=0 \%\right)$ shows no evidence that the effect of vitamin $C$ is different between the trials that used intravenous administration and those that used oral administration on the outcome "hospital-LOS". 
In Section 4.9. Subgroup Analysis Influence of Control Group: “Vitamin C versus Placebo" versus "Vitamin C versus Standard of Care".

A total of eight studies reported the outcome "cerebral ischemic events" and contributed to the subgroup analysis investigating any possible influence of the control group on the outcome. In four of the eight studies, cerebral ischemic events occurred. We found no evidence of a treatment effect between subgroups (test for subgroup differences $\left(\mathrm{Chi}^{2}=0.55, d f=1(p=0.46), \mathrm{I}^{2}=0 \%\right)$.

A total of thirteen studies contributed to the subgroup analysis investigating any possible influence of the control group on the outcome incidence of "atrial fibrillation". We found evidence of a treatment effect between subgroups (test for subgroup differences $\left(\mathrm{Chi}^{2}=11.84, d f=1(p=0.0006)\right.$, $\mathrm{I}^{2}=91.6 \%$ ) between the trials comparing placebo and trials comparing standard of care for the outcome "atrial fibrillation".

A total of four studies contributed to the subgroup analysis investigating any possible influence of the control group on the outcome "duration of mechanical ventilation. We found a statistical significance in the group comparing vitamin C to placebo $\left(p=0.002, \mathrm{CI}-3.99\right.$ to $\left.-0.93, \mathrm{I}^{2}=0 \%\right)$, but not in the group comparing vitamin $C$ to standard of care $\left(p=0.15, \mathrm{CI}-9.25\right.$ to $\left.1.38, \mathrm{I}^{2}=41 \%\right)$. The test for subgroup differences $\left(\mathrm{Chi}^{2}=0.27, d f=1(p=0.60), \mathrm{I}^{2}=0 \%\right)$ shows no evidence that the effect of vitamin $C$ is different between the trials that with compared to placebo and those that compared to standard of care on the outcome "duration of mechanical ventilation".

A total of nine studies reported the outcome "in-hospital mortality" and contributed to the subgroup analysis investigating any possible influence of the control group on the outcome. In-hospital deaths occurred in only four of these studies and we found no evidence of a treatment effect between subgroups (test for subgroup differences $\left(\mathrm{Chi}^{2}=0.12, d f=1(p=0.73), \mathrm{I}^{2}=0 \%\right)$.

A total of 11 studies contributed to the subgroup analysis investigating any possible influence of the control group on the outcome "ICU-LOS". We found no evidence of a treatment effect between subgroups (test for subgroup differences $\left(\mathrm{Chi}^{2}=0.52\right.$, $\mathrm{df}=1(p=0.47), \mathrm{I}^{2}=0 \%$ ).

A total of eight studies contributed to the subgroup analysis investigating any possible influence of the control group on the outcome "hospital-LOS". We found a statistical significance in the placebo group ( $p<0.00001, \mathrm{CI}-50.48$ to $-29.85, \mathrm{I}^{2}=0 \%$ ). In the standard care group, the treatment effect did not reach statistical significance $\left(p=0.89, \mathrm{CI}-13.90\right.$ to $\left.16.10, \mathrm{I}^{2}=63 \%\right)$. The test for subgroup differences $\left(\mathrm{Chi}^{2}=19.74, \mathrm{df}=1(p<0.00001), \mathrm{I}^{2}=94.9 \%\right)$ shows evidence that the effect of vitamin $\mathrm{C}$ is different between the trials compared to the placebo and those that compared to standard of care on the outcome "hospital-LOS".

\section{In Section 5. Discussion}

In Section 5.1. Quality of the Evidence

The low total number of adverse events as well as the low number of studies contributing to some subgroup analyses (for example "cerebral ischemic events" and "duration of mechanical ventilation") limit the conclusions that may be drawn from the meta-analyses.

In Section 5.3. Agreements and Disagreements with Other Reviews.

Three meta-analyses also found significantly shorter hospital-LOS associated with vitamin C. The authors also add additional appendix materials as below.

Supplementary Materials: The following are available online at http://www.mdpi.com/2072-6643/12/12/3910/s1, due to major changes and efforts for the revision of original manuscript (doi:10.3390/nu11092103), please see all details of revised paper in supplementary material

Conflicts of Interest: The authors declare no conflicts of interest that may be perceived as inappropriately influencing the representation or interpretation of reported research results. 


\section{Appendix C. Risk of Bias Assessment}

Table A1. Alshafey 2017 [3].

\begin{tabular}{|c|c|c|}
\hline Bias & Authors' Judgement & Support for Judgement \\
\hline $\begin{array}{l}\text { Random sequence generation } \\
\text { (selection bias) }\end{array}$ & Unclear risk & Insufficient information to form judgement \\
\hline $\begin{array}{l}\text { Allocation concealment } \\
\text { (selection bias) }\end{array}$ & Unclear risk & Insufficient information to form judgement \\
\hline $\begin{array}{l}\text { Blinding of participants and } \\
\text { personnel (performance bias) }\end{array}$ & High risk & No blinding of participants and personnel \\
\hline $\begin{array}{l}\text { Blinding of outcome assessment } \\
\text { (detection bias) }\end{array}$ & High risk & No blinding of outcome assessment \\
\hline $\begin{array}{c}\text { Incomplete outcome data } \\
\text { (attrition bias) }\end{array}$ & Low risk & All data reported \\
\hline $\begin{array}{l}\text { Selective reporting } \\
\text { (reporting bias) }\end{array}$ & Unclear risk & $\begin{array}{l}\text { All outcomes stated in the methods section were } \\
\text { adequately reported or explained in results }\end{array}$ \\
\hline Other bias & Unclear risk & $\begin{array}{l}\text { Funding for trial: not reported } \\
\text { Notable conflicts of interest of authors: not reportec }\end{array}$ \\
\hline
\end{tabular}

Table A2. Antonic 2016 [4].

\begin{tabular}{|c|c|c|}
\hline Bias & Authors' Judgement & Support for Judgement \\
\hline $\begin{array}{l}\text { Random sequence generation } \\
\text { (selection bias) }\end{array}$ & Unclear risk & Insufficient information to form judgement \\
\hline $\begin{array}{l}\text { Allocation concealment } \\
\text { (selection bias) }\end{array}$ & Unclear risk & Insufficient information to form judgement \\
\hline $\begin{array}{l}\text { Blinding of participants and } \\
\text { personnel (performance bias) }\end{array}$ & High risk & No blinding of participants and personnel \\
\hline $\begin{array}{l}\text { Blinding of outcome assessment } \\
\text { (detection bias) }\end{array}$ & High risk & No blinding of outcome assessment \\
\hline $\begin{array}{c}\text { Incomplete outcome data } \\
\text { (attrition bias) }\end{array}$ & Low risk & All data reported \\
\hline $\begin{array}{l}\text { Selective reporting } \\
\text { (reporting bias) }\end{array}$ & Low risk & $\begin{array}{c}\text { All outcomes stated in the methods section were } \\
\text { adequately reported or explained in results } \\
\text { Funding for trial: no funding }\end{array}$ \\
\hline Other bias & Low risk & $\begin{array}{l}\text { Notable conflicts of interest of authors: all authors } \\
\text { declare no conflict of interest }\end{array}$ \\
\hline
\end{tabular}

Table A3. Antonic 2017 [5].

\begin{tabular}{ccc}
\hline Bias & Authors' Judgement & Support for Judgement \\
\hline $\begin{array}{c}\text { Random sequence generation } \\
\text { (selection bias) }\end{array}$ & Unclear risk & Insufficient information to form judgement \\
$\begin{array}{c}\text { Allocation concealment } \\
\text { (selection bias) }\end{array}$ & Unclear risk & Insufficient information to form judgement \\
$\begin{array}{c}\text { Blinding of participants and } \\
\text { personnel (performance bias) } \\
\text { Blinding of outcome assessment } \\
\begin{array}{c}\text { (detection bias) } \\
\text { Incomplete outcome data } \\
\text { (attrition bias) }\end{array}\end{array}$ & High risk & No blinding of participants and personnel \\
$\begin{array}{c}\text { Selective reporting } \\
\text { (reporting bias) } \\
\text { Other bias }\end{array}$ & Low risk & No blinding of outcome assessment \\
Low risk & Unclear risk & $\begin{array}{c}\text { All data reported } \\
\text { adequately reported or explained in results } \\
\text { Funding for trial: not reported }\end{array}$ \\
\hline
\end{tabular}


Table A4. Bakr 2015 [6].

\begin{tabular}{ccc}
\hline Bias & Authors' Judgement & Support for Judgement \\
\hline $\begin{array}{c}\text { Random sequence generation } \\
\text { (selection bias) }\end{array}$ & Unclear risk & Insufficient information to form judgement \\
$\begin{array}{c}\text { Allocation concealment } \\
\text { (selection bias) }\end{array}$ & Unclear risk & Insufficient information to form judgement \\
$\begin{array}{c}\text { Blinding of participants and } \\
\text { personnel (performance bias) } \\
\text { Blinding of outcome assessment } \\
\text { (detection bias) }\end{array}$ & Unclear risk & Insufficient information to form judgement \\
$\begin{array}{c}\text { Incomplete outcome data } \\
\text { (attrition bias) } \\
\text { Selective reporting } \\
\text { (reporting bias) }\end{array}$ & Unclear risk & Insufficient information to form judgement \\
Other bias & Unclear risk & Insufficient information to form judgement \\
& Unclear risk & Insufficient information to form judgement \\
Funding for trial: not reported
\end{tabular}

Table A5. Bjordahl 2012 [7].

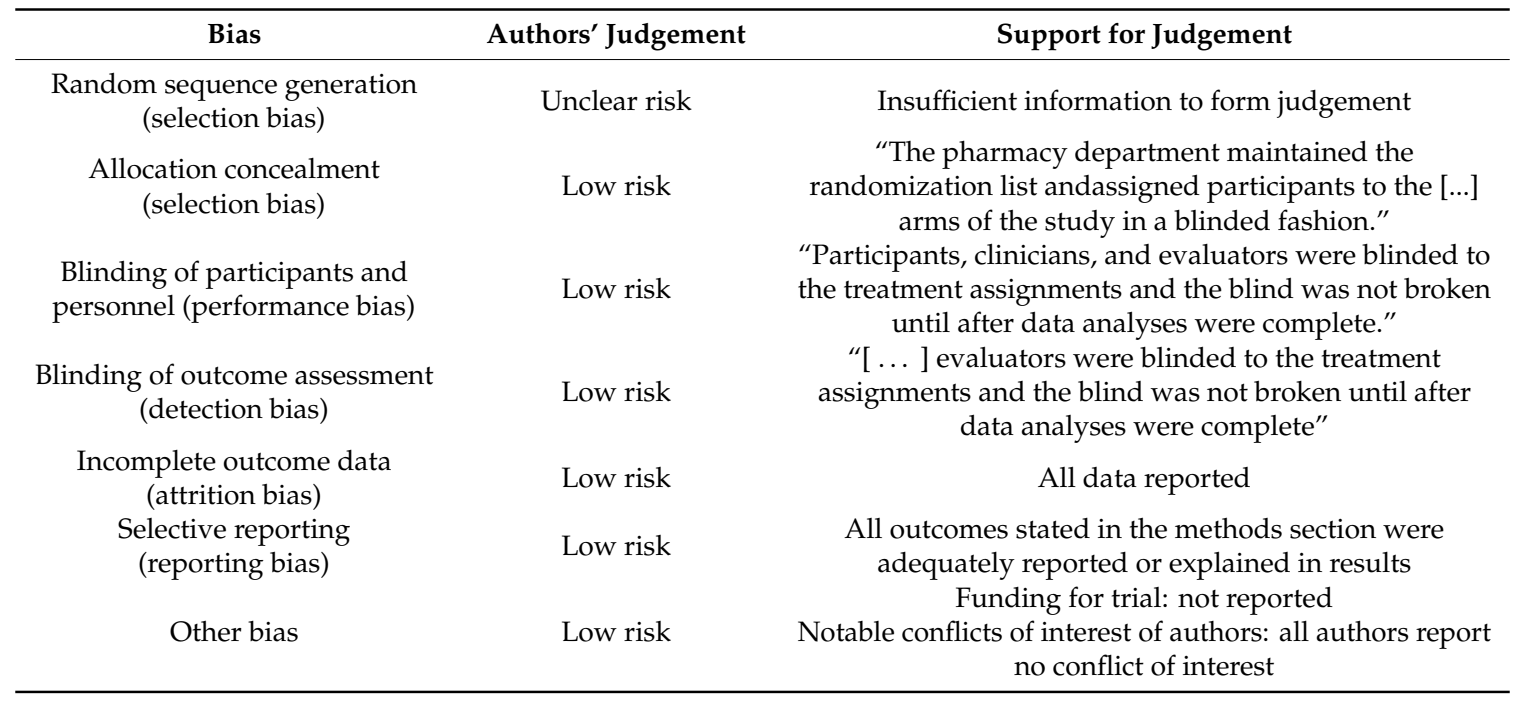

Table A6. Colby 2011 [8].

\begin{tabular}{|c|c|c|}
\hline Bias & Authors' Judgement & Support for Judgement \\
\hline $\begin{array}{l}\text { Random sequence generation } \\
\text { (selection bias) }\end{array}$ & Low risk & $\begin{array}{c}\text { "Eligible patients were randomized using a } \\
\text { computer-generated sequence with a } 1: 1 \text { allocation and a } \\
\text { random block size of } 10 . "\end{array}$ \\
\hline $\begin{array}{l}\text { Allocation concealment } \\
\quad \text { (selection bias) }\end{array}$ & Low risk & $\begin{array}{c}\text { "Eligible patients were randomized using a } \\
\text { computer-generated sequence with a 1:1 allocation and a } \\
\text { random block size of } 10 . "\end{array}$ \\
\hline $\begin{array}{l}\text { Blinding of participants and } \\
\text { personnel (performance bias) }\end{array}$ & Low risk & $\begin{array}{l}\text { "Study patients, cardiothoracic surgeons, caregivers, } \\
\text { and investigators, including those responsible for data } \\
\text { collection, were blinded to the treatment allocation." }\end{array}$ \\
\hline $\begin{array}{l}\text { Blinding of outcome assessment } \\
\text { (detection bias) }\end{array}$ & Low risk & $\begin{array}{l}\text { "Study patients, cardiothoracic surgeons, caregivers, } \\
\text { and investigators, including those responsible for data } \\
\text { collection, were blinded to the treatment allocation." }\end{array}$ \\
\hline $\begin{array}{l}\text { Incomplete outcome data } \\
\text { (attrition bias) }\end{array}$ & Low risk & $\begin{array}{l}\text { All data reported (one patient excluded from analysis as } \\
\text { the patient did not receive the study drug) }\end{array}$ \\
\hline $\begin{array}{l}\text { Selective reporting } \\
\text { (reporting bias) }\end{array}$ & Low risk & $\begin{array}{l}\text { All outcomes stated in the methods section were } \\
\text { adequately reported or explained in results }\end{array}$ \\
\hline Other bias & Low risk & $\begin{array}{c}\text { Funding for trial: Gustavus and Luise Pfeiffer Research } \\
\text { Foundation, the sponsor played no role in the design, } \\
\text { execution, analysis or submission of the trial and } \\
\text { its results } \\
\text { Notable conflicts of interest of authors: all authors report } \\
\text { no conflict of interest }\end{array}$ \\
\hline
\end{tabular}


Table A7. Dehghani 2014 [9].

\begin{tabular}{|c|c|c|}
\hline Bias & Authors' Judgement & Support for Judgement \\
\hline $\begin{array}{l}\text { Random sequence generation } \\
\text { (selection bias) }\end{array}$ & Low risk & $\begin{array}{l}\text { "Patients were randomized into two groups in a 1:1 } \\
\text { ratio using random-number table." }\end{array}$ \\
\hline $\begin{array}{l}\text { Allocation concealment } \\
\quad \text { (selection bias) }\end{array}$ & Unclear risk & Insufficient information to form judgement \\
\hline $\begin{array}{l}\text { Blinding of participants and } \\
\text { personnel (performance bias) }\end{array}$ & High risk & No blinding of participants and personnel \\
\hline $\begin{array}{l}\text { Blinding of outcome assessment } \\
\text { (detection bias) }\end{array}$ & High risk & No blinding of outcome assessment \\
\hline $\begin{array}{l}\text { Incomplete outcome data } \\
\text { (attrition bias) }\end{array}$ & Low risk & All data reported \\
\hline $\begin{array}{l}\text { Selective reporting } \\
\text { (reporting bias) }\end{array}$ & Low risk & $\begin{array}{l}\text { All outcomes stated in the methods section were } \\
\text { adequately reported or explained in results }\end{array}$ \\
\hline Other bias & Unclear risk & $\begin{array}{l}\text { Funding for trial: not reported } \\
\text { Notable conflicts of interest of authors: all authors } \\
\text { report no conflict of interest }\end{array}$ \\
\hline
\end{tabular}

Table A8. Demirag 2001 [10].

\begin{tabular}{ccc}
\hline Bias & Authors' Judgement & Support for Judgement \\
\hline $\begin{array}{c}\text { Random sequence generation } \\
\text { (selection bias) }\end{array}$ & Unclear risk & Insufficient information to form judgement \\
$\begin{array}{c}\text { Allocation concealment } \\
\text { (selection bias) }\end{array}$ & Unclear risk & Insufficient information to form judgement \\
$\begin{array}{c}\text { Blinding of participants and } \\
\text { personnel (performance bias) } \\
\text { Blinding of outcome assessment } \\
\text { (detection bias) }\end{array}$ & High risk & No blinding of participants and personnel \\
$\begin{array}{c}\text { Incomplete outcome data } \\
\text { (attrition bias) }\end{array}$ & High risk & No blinding of outcome assessment \\
$\begin{array}{c}\text { Selective reporting } \\
\text { (reporting bias) } \\
\text { Other bias }\end{array}$ & Low risk & $\begin{array}{c}\text { All data reported } \\
\text { adequately reported or explained in results } \\
\text { Funding for trial: not reported }\end{array}$ \\
\hline
\end{tabular}

Table A9. Donovan 2012 [11].

\begin{tabular}{|c|c|c|}
\hline Bias & Authors' Judgement & Support for Judgement \\
\hline $\begin{array}{l}\text { Random sequence generation } \\
\text { (selection bias) }\end{array}$ & Unclear risk & Insufficient information to form judgement \\
\hline $\begin{array}{l}\text { Allocation concealment } \\
\text { (selection bias) }\end{array}$ & Unclear risk & Insufficient information to form judgement \\
\hline $\begin{array}{l}\text { Blinding of participants and } \\
\text { personnel (performance bias) }\end{array}$ & Unclear risk & Insufficient information to form judgement \\
\hline $\begin{array}{l}\text { Blinding of outcome assessment } \\
\text { (detection bias) }\end{array}$ & Unclear risk & Insufficient information to form judgement \\
\hline $\begin{array}{l}\text { Incomplete outcome data } \\
\text { (attrition bias) }\end{array}$ & Unclear risk & Insufficient information to form judgement \\
\hline $\begin{array}{l}\text { Selective reporting } \\
\text { (reporting bias) }\end{array}$ & Unclear risk & Insufficient information to form judgement \\
\hline Other bias & Unclear risk & $\begin{array}{l}\text { Funding for trial: not reported } \\
\text { Notable conflicts of interest of authors: not reported }\end{array}$ \\
\hline
\end{tabular}


Table A10. Eslami 2007 [12].

\begin{tabular}{|c|c|c|}
\hline Bias & Authors' Judgement & Support for Judgement \\
\hline $\begin{array}{l}\text { Random sequence generation } \\
\text { (selection bias) }\end{array}$ & Unclear risk & Insufficient information to form judgement \\
\hline $\begin{array}{l}\text { Allocation concealment } \\
\quad \text { (selection bias) }\end{array}$ & Unclear risk & Insufficient information to form judgement \\
\hline $\begin{array}{l}\text { Blinding of participants and } \\
\text { personnel (performance bias) }\end{array}$ & High risk & No blinding of participants and personnel \\
\hline $\begin{array}{l}\text { Blinding of outcome assessment } \\
\text { (detection bias) }\end{array}$ & Low risk & $\begin{array}{c}\text { "Echocardiography [..] was performed before surgery by a } \\
\text { single investigator in a blinded fashion." } \\
\text { "All of the Holter recordings were examined by a single } \\
\text { investigator who had been blinded to patients' } \\
\text { group assignments." }\end{array}$ \\
\hline $\begin{array}{l}\text { Incomplete outcome data } \\
\text { (attrition bias) }\end{array}$ & Low risk & All data reported \\
\hline $\begin{array}{l}\text { Selective reporting } \\
\text { (reporting bias) }\end{array}$ & Low risk & $\begin{array}{l}\text { All outcomes stated in the methods section were } \\
\text { adequately reported or explained in results }\end{array}$ \\
\hline Other bias & Unclear risk & $\begin{array}{c}\text { Funding for trial: This study was supported in part by a } \\
\text { research grant from Tehran University of Medical } \\
\text { SciencesNotable conflicts of interest of authors: } \\
\text { not reported }\end{array}$ \\
\hline
\end{tabular}

Table A11. Healy 2010 [13].

\begin{tabular}{ccc}
\hline Bias & Authors' Judgement & Support for Judgement \\
\hline $\begin{array}{c}\text { Random sequence generation } \\
\text { (selection bias) } \\
\begin{array}{c}\text { Allocation concealment } \\
\text { (selection bias) }\end{array}\end{array}$ & Unclear risk & Unclear risk \\
$\begin{array}{c}\text { Blinding of participants and } \\
\text { personnel (performance bias) } \\
\text { Blinding of outcome assessment } \\
\text { (detection bias) }\end{array}$ & High risk & Insufficient information to form judgement \\
$\begin{array}{c}\text { Incomplete outcome data } \\
\text { (attrition bias) } \\
\begin{array}{c}\text { Selective reporting } \\
\text { (reporting bias) }\end{array}\end{array}$ & High risk & No blinding of participants and personnel \\
Other bias & Unclear risk & Insufficient information to form judgement \\
& Unclear risk & Insufficient information to form judgement \\
& Funding for trial: not reported
\end{tabular}

Table A12. Jouybar 2012 [14].

\begin{tabular}{|c|c|c|}
\hline Bias & Authors' Judgement & Support for Judgement \\
\hline $\begin{array}{l}\text { Random sequence generation } \\
\text { (selection bias) }\end{array}$ & Low risk & $\begin{array}{l}\text { "The patients were randomly assigned to two groups according } \\
\text { to the printed table of random numbers, to either receive [...]." } \\
\text { "A blinded anesthesiologist who was involved neither in the } \\
\text { patients' allocation and management nor in the design of the } \\
\text { study and data processing and analysis, generated the } \\
\text { randomization list using a computer program." }\end{array}$ \\
\hline $\begin{array}{l}\text { Allocation concealment } \\
\text { (selection bias) }\end{array}$ & Unclear risk & Insufficient information to form judgement \\
\hline $\begin{array}{l}\text { Blinding of participants and } \\
\text { personnel (performance bias) }\end{array}$ & Unclear risk & $\begin{array}{c}\text { "Moreover, the physician responsible for managing the patients } \\
\text { did not participate in the study." }\end{array}$ \\
\hline $\begin{array}{l}\text { Blinding of outcome assessment } \\
\text { (detection bias) }\end{array}$ & Low risk & $\begin{array}{c}\text { No blinding of outcome assessment, however, only outcomes } \\
\text { were laboratory measures, lack of blinding has minor impact of } \\
\text { evaluation of these endpoints }\end{array}$ \\
\hline $\begin{array}{l}\text { Incomplete outcome data } \\
\text { (attrition bias) }\end{array}$ & Low risk & $\begin{array}{l}10 \% \text { of patients not treated according to protocol, excluded } \\
\text { from analysis }\end{array}$ \\
\hline $\begin{array}{l}\text { Selective reporting } \\
\text { (reporting bias) }\end{array}$ & Unclear risk & $\begin{array}{l}\text { All outcomes stated in the methods section were adequately } \\
\text { reported or explained in results }\end{array}$ \\
\hline Other bias & Low risk & $\begin{array}{c}\text { Funding for trial: This work was supported by Shiraz University } \\
\text { of Medical } \\
\text { Sciences } \\
\text { Notable conflicts of interest of authors: all authors report no } \\
\text { conflict of interest }\end{array}$ \\
\hline
\end{tabular}


Table A13. Knodell 1981 [15].

\begin{tabular}{|c|c|c|}
\hline Bias & Authors' Judgement & Support for Judgement \\
\hline $\begin{array}{l}\text { Random sequence generation } \\
\text { (selection bias) }\end{array}$ & Unclear risk & Insufficient information to form judgement \\
\hline $\begin{array}{l}\text { Allocation concealment } \\
\quad \text { (selection bias) }\end{array}$ & Unclear risk & Insufficient information to form judgement \\
\hline $\begin{array}{l}\text { Blinding of participants and } \\
\text { personnel (performance bias) }\end{array}$ & Low risk & "double-blind trial" \\
\hline $\begin{array}{l}\text { Blinding of outcome assessment } \\
\text { (detection bias) }\end{array}$ & Low risk & $\begin{array}{l}\text { "Clinical and laboratory data sheets on all patients } \\
\text { with even minor enzyme elevations were submitted } \\
\text { to two independent rereviewers [...] for evaluation." } \\
\text { "These reviewers either accepted or rejected patients } \\
\text { as cases of posttransfusion hepatitis, and analysis of } \\
\text { data was based on their decisions." }\end{array}$ \\
\hline $\begin{array}{l}\text { Incomplete outcome data } \\
\text { (attrition bias) }\end{array}$ & High risk & $\begin{array}{l}\text { "40 patients [...] who did not complete the study } \\
\text { were distributed equally between the placebo and } \\
\text { vitamin C treatment groups. The vast majority of } \\
\text { patients who did not complete the study either } \\
\text { refused to take the study medication postoperatively } \\
\text { (11 patients in each group) or refused to have } \\
\text { follow-up blood samples drawn." }\end{array}$ \\
\hline $\begin{array}{l}\text { Selective reporting } \\
\text { (reporting bias) }\end{array}$ & High risk & $\begin{array}{c}\text { All outcomes stated in the methods section are NOT } \\
\text { adequately reported or explained in results: } \\
\text { Serum aminotransferases (only SGPT, SGOT missing } \\
\text { Alkaline phosphatase missing } \\
\text { Symptoms of congestive heart failure, one month } \\
\text { intervals missing }\end{array}$ \\
\hline Other bias & Unclear risk & $\begin{array}{l}\text { Funding for trial: Hoffmann-LaRoche and the } \\
\text { Veterans Research Service } \\
\text { Notable conflicts of interest of authors: not reported }\end{array}$ \\
\hline
\end{tabular}

Table A14. Papoulidis 2011 [16].

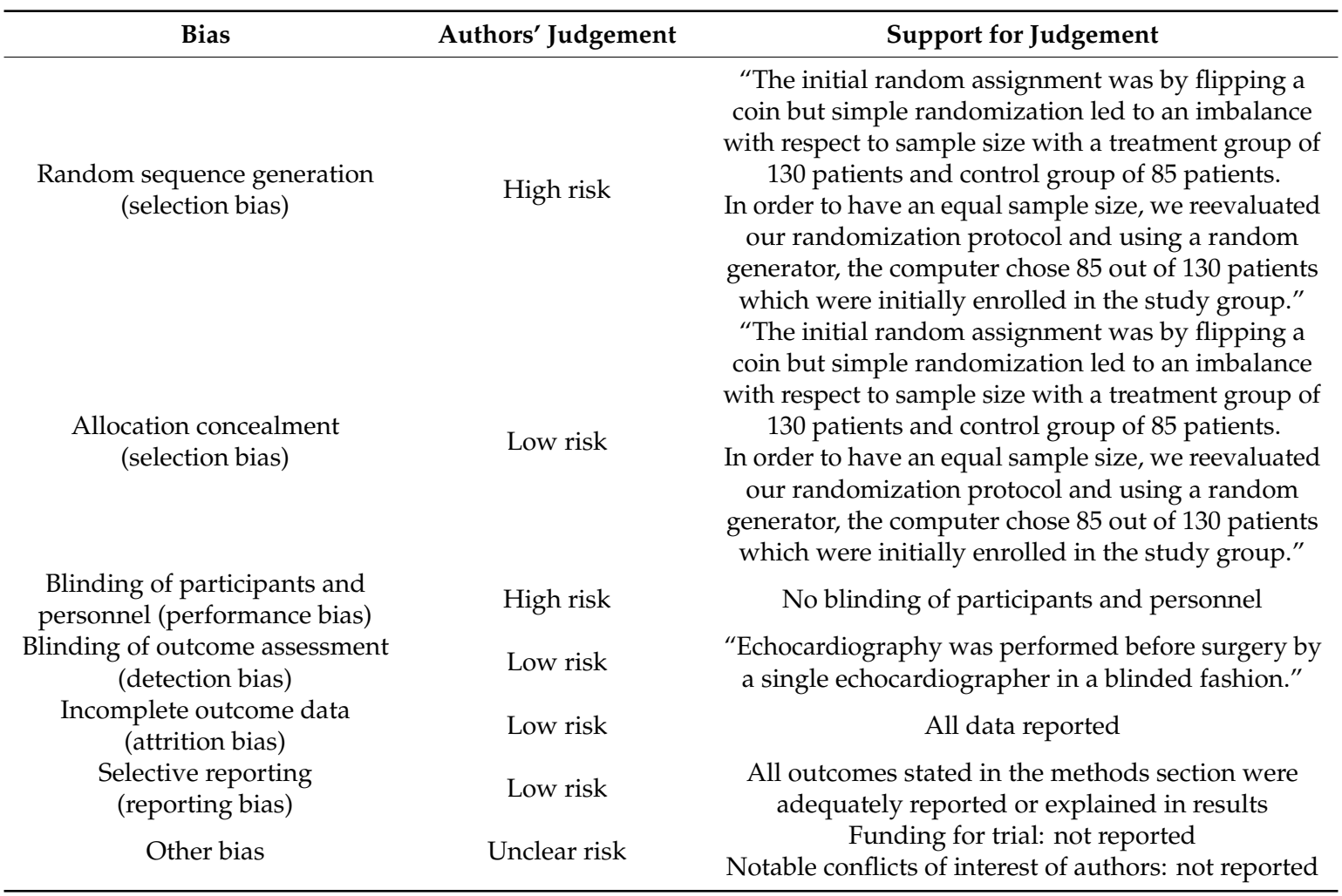


Table A15. Polymeropoulos 2015 [17].

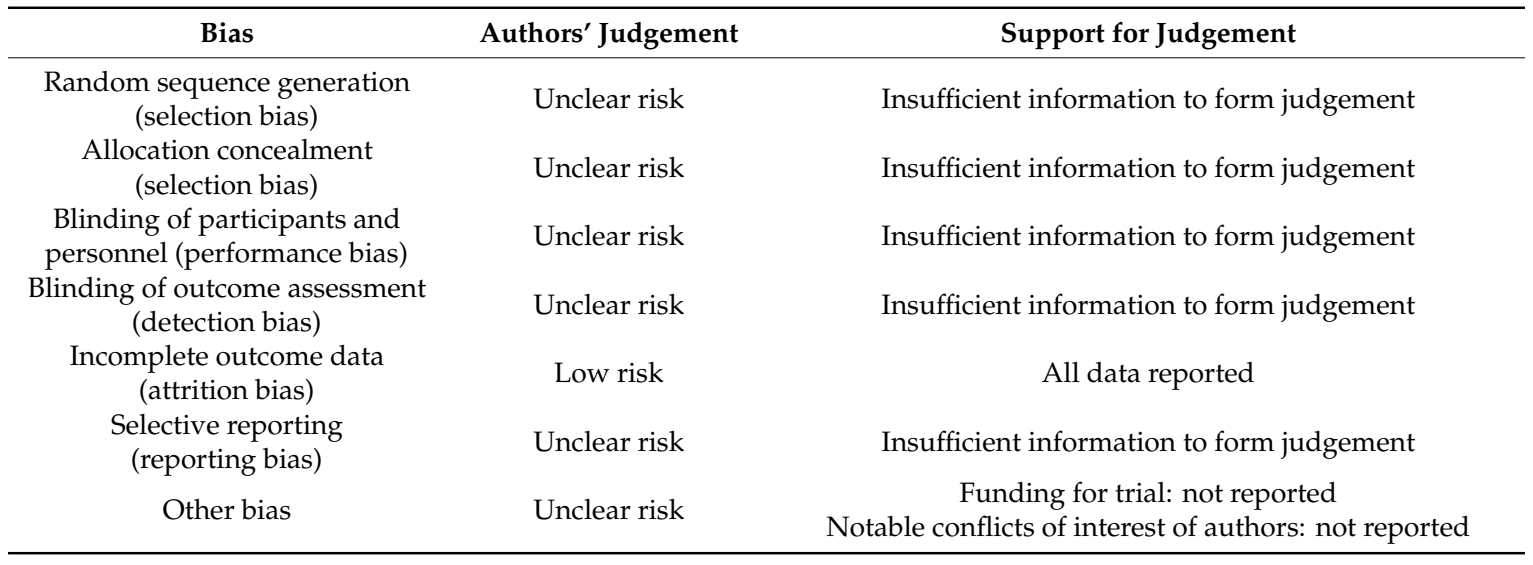

Table A16. Sadeghpour 2015 [18].

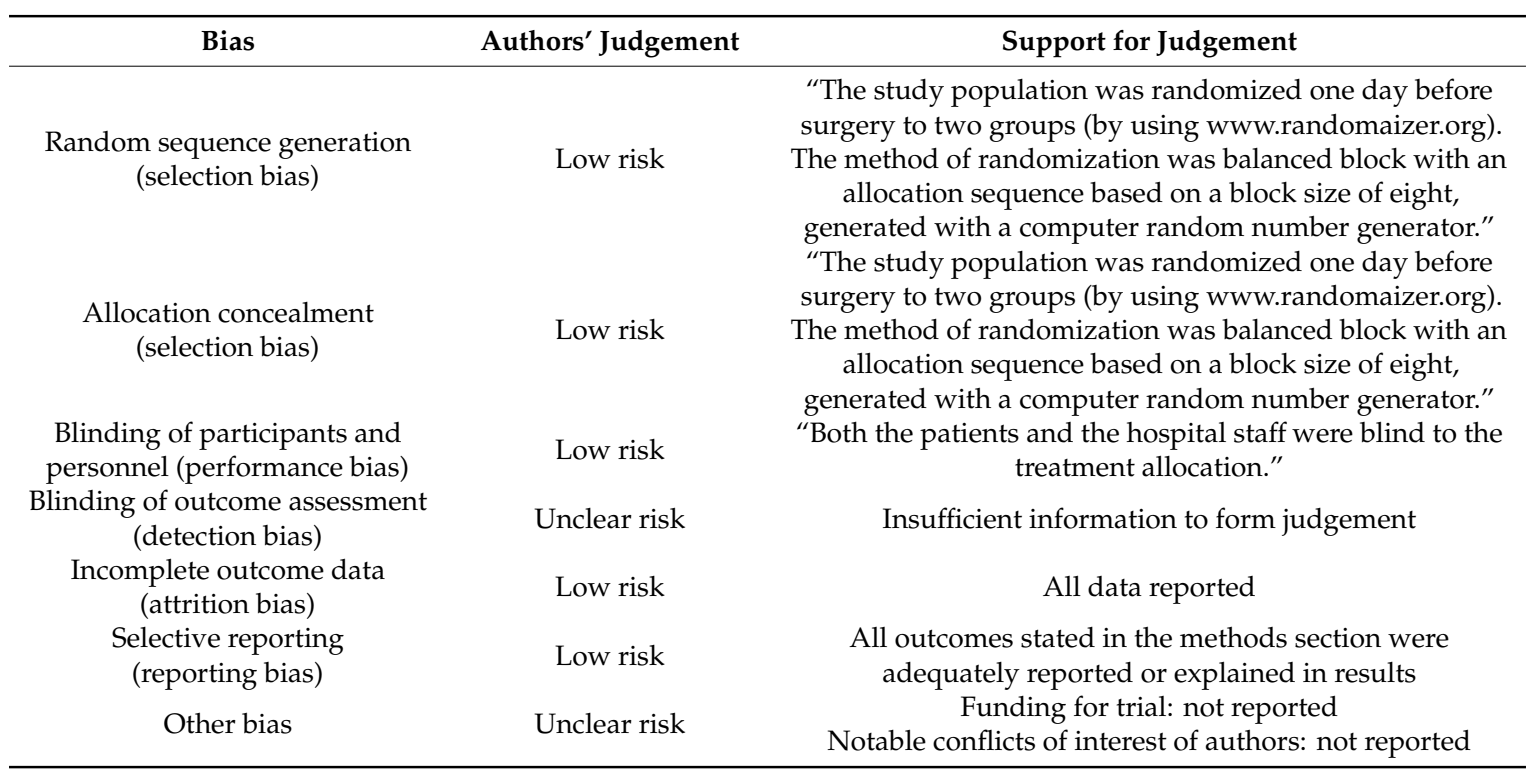

Table A17. Safaei 2017 [19].

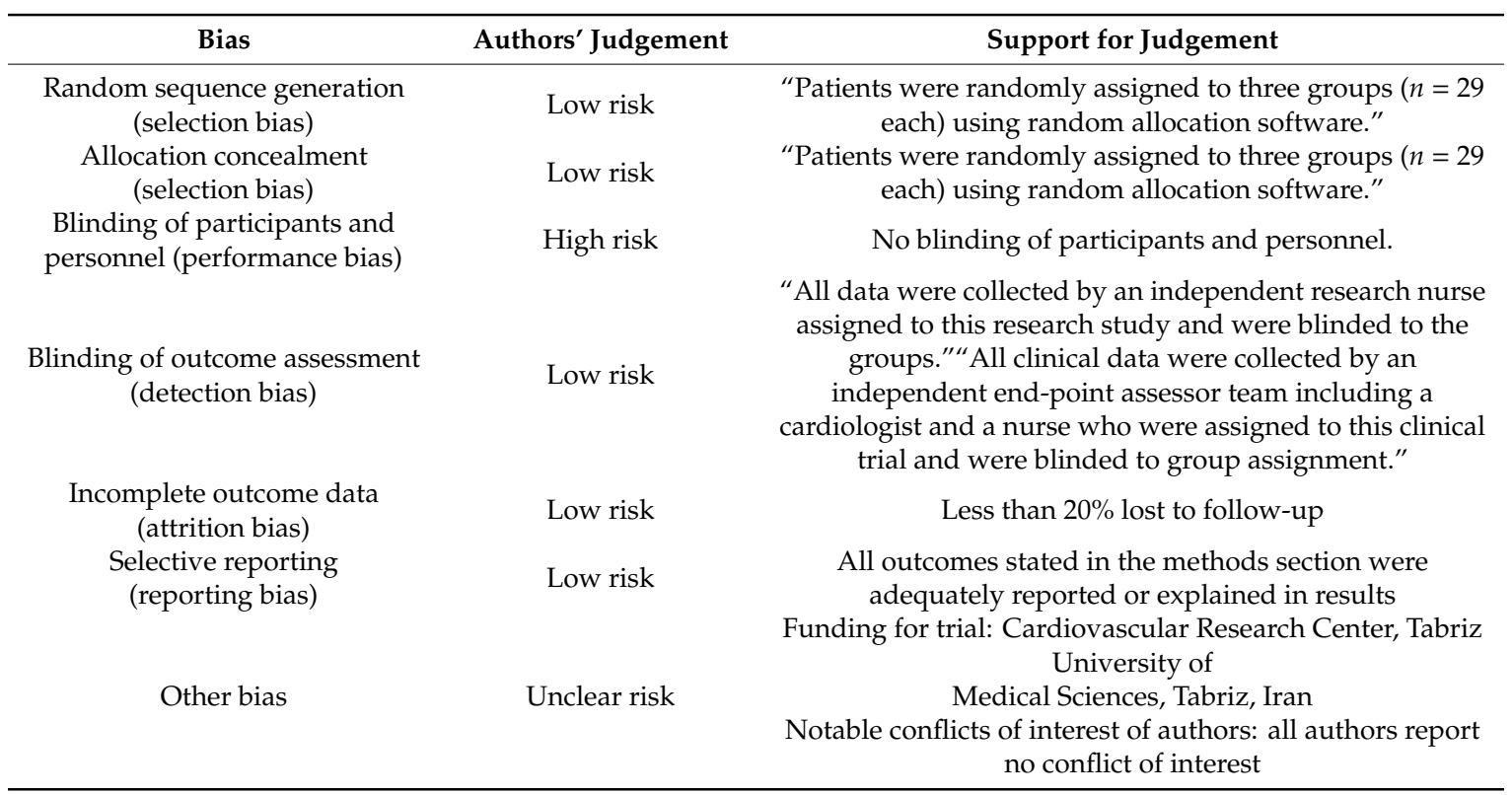


Table A18. Sarzaeem 2014 [20].

\begin{tabular}{|c|c|c|}
\hline Bias & Authors' Judgement & Support for Judgement \\
\hline $\begin{array}{l}\text { Random sequence generation } \\
\text { (selection bias) }\end{array}$ & Unclear risk & $\begin{array}{l}\text { Insufficient information to form judgement, study } \\
\text { reported in Farsi, translation difficult }\end{array}$ \\
\hline $\begin{array}{l}\text { Allocation concealment } \\
\text { (selection bias) }\end{array}$ & Unclear risk & $\begin{array}{l}\text { Insufficient information to form judgement, study } \\
\text { reported in Farsi, translation difficult }\end{array}$ \\
\hline $\begin{array}{l}\text { Blinding of participants and } \\
\text { personnel (performance bias) }\end{array}$ & Unclear risk & $\begin{array}{l}\text { Insufficient information to form judgement, study } \\
\text { reported in Farsi, translation difficult }\end{array}$ \\
\hline $\begin{array}{l}\text { Blinding of outcome assessment } \\
\text { (detection bias) }\end{array}$ & Unclear risk & $\begin{array}{l}\text { Insufficient information to form judgement, study } \\
\text { reported in Farsi, translation difficult }\end{array}$ \\
\hline $\begin{array}{c}\text { Incomplete outcome data } \\
\text { (attrition bias) }\end{array}$ & Unclear risk & $\begin{array}{l}\text { Insufficient information to form judgement, study } \\
\text { reported in Farsi, translation difficult }\end{array}$ \\
\hline $\begin{array}{l}\text { Selective reporting } \\
\text { (reporting bias) }\end{array}$ & Unclear risk & $\begin{array}{l}\text { Insufficient information to form judgement, study } \\
\text { reported in Farsi, translation difficult }\end{array}$ \\
\hline Other bias & Unclear risk & $\begin{array}{l}\text { Insufficient information to form judgement, study } \\
\text { reported in Farsi, translation difficult }\end{array}$ \\
\hline
\end{tabular}

Table A19. Van Wagoner 2003 [21].

\begin{tabular}{|c|c|c|}
\hline Bias & Authors' Judgement & Support for Judgement \\
\hline $\begin{array}{l}\text { Random sequence generation } \\
\text { (selection bias) }\end{array}$ & Unclear risk & Insufficient information to form judgement \\
\hline $\begin{array}{l}\text { Allocation concealment } \\
\quad \text { (selection bias) }\end{array}$ & Unclear risk & Insufficient information to form judgement \\
\hline $\begin{array}{l}\text { Blinding of participants and } \\
\text { personnel (performance bias) }\end{array}$ & Unclear risk & Insufficient information to form judgement \\
\hline $\begin{array}{l}\text { Blinding of outcome assessment } \\
\text { (detection bias) }\end{array}$ & Unclear risk & Insufficient information to form judgement \\
\hline $\begin{array}{l}\text { Incomplete outcome data } \\
\text { (attrition bias) }\end{array}$ & Unclear risk & Insufficient information to form judgement \\
\hline $\begin{array}{l}\text { Selective reporting } \\
\text { (reporting bias) }\end{array}$ & Unclear risk & Insufficient information to form judgement \\
\hline Other bias & Unclear risk & $\begin{array}{l}\text { Funding for trial: not reported } \\
\text { Notable conflicts of interest of authors: all authors } \\
\text { report no conflict of interest }\end{array}$ \\
\hline
\end{tabular}

\section{References}

1. Hemilä, H.; Chalker, E. Vitamin C for Cardiac Surgery Patients: Several Errors in a Published Meta-Analysis. Comment on "Effects of Vitamin C on Organ Function in Cardiac Surgery Patients: A Systematic Review and Meta-Analysis. Nutrients 2019, 11, 2103". Nutrients 2020, 12, 586. [CrossRef]

2. Hill, A.; Clasen, K.C.; Wendt, S.; Majoros, Á.G.; Stoppe, C.; Adhikari, N.K.J.; Heyland, D.K.; Benstoem, C. Effects of Vitamin C on Organ Function in Cardiac Surgery Patients: A Systematic Review and Meta-Analysis. Nutrients 2019, 11, 2103. [CrossRef]

3. Mohammed, K.A.; Alshafey, M.D.; Hany, K.; Elrakhawy, H.M.; Rezk, M.E.M.D.; Moataz, E.R.M.D.; Hani, M.M.M.S.C.; Moustafa, H.M. Role of ascorbic acid in reduction of the incidence of the atrial fibrillation in patients under bB-blocker and undergoing coronary artery bypass graft operation in early post-operative period. J. Egypt. Soc. Cardio Thorac.-Thoracic Surg. 2017, 25, 198-203. [CrossRef]

4. Antonic, M.; Lipovec, R.; Gregorcic, F.; Juric, P.; Kosir, G. Perioperative ascorbic acid supplementation does not reduce the incidence of postoperative atrial fibrillation in on-pump coronary artery bypass graft patients. J. Cardiol. 2017, 69, 98-102. [CrossRef]

5. Antonic, M. Effect of Ascorbic Acid on Postoperative Acute Kidney Injury in Coronary Artery Bypass Graft Patients: A Pilot Study. Hear. Surg. Forum 2017, 20, 214. [CrossRef] [PubMed]

6. Bakr, H.; Elsayegh, T.; El Fatah, M.A. 2. Role of ascorbic acid \& statin in reduction of the incidence of the atrial fibrillation in patients under B-blocker and undergoing coronary artery bypass graft operation in early post-operative period. J. Saudi Hear. Assoc. 2015, 27, 299-300. [CrossRef] 
7. Bjordahl, P.M.; Helmer, S.; Gosnell, D.J.; Wemmer, G.E.; O'Hara, W.W.; Milfeld, D.J. Perioperative supplementation with ascorbic acid does not prevent atrial fibrillation in coronary artery bypass graft patients. Am. J. Surg. 2012, 204, 862-867. [CrossRef] [PubMed]

8. Colby, J.A.; Chen, W.T.; Baker, W.L.; Coleman, C.I.; Reinhart, K.; Kluger, J.; White, C.M. Effect of ascorbic acid on inflammatory markers after cardiothoracic surgery. Am. J. Heal. Pharm. 2011, 68, 1632-1639. [CrossRef] [PubMed]

9. Dehghani, M.R.; Madjidi, N.; Rahmani, A.; Askari, B.; Rezaei, Y. Effect of oral vitamin C on atrial fibrillation development after isolated coronary artery bypass grafting surgery: A prospective randomized clinical trial. Cardiol. J. 2014, 21, 492-499. [CrossRef] [PubMed]

10. Demirag, K.; Askar, F.Z.; Uyar, M.; Cevik, A.; Ozmen, D.; Mutaf, I.; Bayindir, O. The protective effects of high dose ascorbic acid and diltiazem on myocardial ischaemia-reperfusion injury. Middle East J. Anaesthesiol. 2001, 16, 67-79. [PubMed]

11. Donovan, P.C.; Kramer, R.S. Prophylaxis to Reduce Postoperative Atrial Fibrillation in Cardiac Surgery, nct00953212. Available online: https://clinicaltrials.gov/ct2/show/NCT00953212 (accessed on 23 November 2018).

12. Eslami, M.; Badkoubeh, R.S.; Mousavi, M.; Radmehr, H.; Salehi, M.; Tavakoli, N.; Avadi, M.R. Oral Ascorbic Acid in Combination with Beta-Blockers Is More Effective than Beta-Blockers Alone in the Prevention of Atrial Fibrillation after Coronary Artery Bypass Grafting. Tex. Hear. Inst. J. 2007, 34, 268-274.

13. Healy, R.M.; Day, D.; van Gorder, C. Ascorbic acid utilization for atrial-fibrillation prophylaxis post coronary-artery-bypass graft and valve replacement surgeries: An interim analysis of a prospective, randomized study. Pharmacotherapy 2010, 30, 445e-446e.

14. Jouybar, R.; Kabgani, H.; Kamalipour, H.; Shahbazi, S.; Allahyary, E.; Rasouli, M.; Akhlagh, S.H.; Shafa, M.; Ghazinoor, M.; Moeinvaziri, M.T.; et al. The perioperative effect of ascorbic acid on inflammatory response in coronary artery bypass graft surgery; a randomized controlled trial coronary artery bypass graft surgery. Int. Cardiovasc. Res. J. 2012, 6, 13-17.

15. Knodell, R.G.; A Tate, M.; Akl, B.F.; Wilson, J.W. Vitamin C prophylaxis for posttransfusion hepatitis: Lack of effect in a controlled trial. Am. J. Clin. Nutr. 1981, 34, 20-23. [CrossRef] [PubMed]

16. Papoulidis, P.; Ananiadou, O.; Chalvatzoulis, E.; Ampatzidou, F.; Koutsogiannidis, C.; Karaiskos, T.; Madesis, A.; Drossos, G. The role of ascorbic acid in the prevention of atrial fibrillation after elective on-pump myocardial revascularization surgery: A single-center experience-A pilot study. Interact. Cardiovasc. Thorac. Surg. 2011, 12, 121-124. [CrossRef]

17. Polymeropoulos, E. Vitamin c for Prophylaxis of Post-Operative Atrial Fibrillation in on-Pump Cardiac Surgery Procedures, nct01107730. Available online: https://clinicaltrials.gov/ct2/show/NCT00953212 (accessed on 23 November 2018).

18. Sadeghpour, A.; Alizadehasl, A.; Kyavar, M.; Sadeghi, T.; Moludi, J.; Gholizadeh, F.; Totonchi, Z.; Ghadrdoost, B. Impact of Vitamin C Supplementation on Post-Cardiac Surgery ICU and Hospital Length of Stay. Anesthesiol. Pain Med. 2015, 5, 25337. [CrossRef] [PubMed]

19. Babaei, H.; Safaie, N.; Azarfarin, R.; Jodati, A.; Yaghoubi, A.; Sheikhalizadeh, M.-A. Comparative effect of grape seed extract (Vitis vinifera) and ascorbic acid in oxidative stress induced by on-pump coronary artery bypass surgery. Ann. Card. Anaesth. 2017, 20,45-51. [CrossRef]

20. Sarzaeem, M.; Shayan, N. Vitamin c in prevention of atrial fibrillation after coronary artery bypass graft: Double blind randomized clinical trial. Tehran Univ. Med. J. 2014, 71, 2014.

21. Van Wagoner, D.R.; Palumbo, R.; Li, J.; Carnes, C.A.; Gillinov, A.; McCarthy, P.M.; Chung, M.K. Supplemental vitamin $\mathrm{c}$ did not reduce the incidence of atrial arrhythmia following cardiac bypass surgery. Heart Rhytm Society. 2003. Available online: http://www.mv.helsinki.fi/home/hemila/CAF/vanWagoner2003.pdf (accessed on 4 December 2016).

Publisher's Note: MDPI stays neutral with regard to jurisdictional claims in published maps and institutional affiliations. 